\section{A rapid simplified method for plasma 25-hydroxyvitamin D estimation}

JUDITH C HAMILTON South Laboratory and Pathology Block, Southampton General Hospital, Southampton SO9 $4 X Y, U K$

Low plasma 25-hydroxyvitamin D (25-OHD) concentrations are common in elderly people, orthopaedic patients, Asian immigrants, and in the later stages of pregnancy. ${ }^{1-3}$ Though a low plasma 25-OHD concentration is not always associated with osteomalacia, there is circumstantial evidence that, in old people at least, low 25-OHD levels if left untreated may ultimately lead to metabolic bone disease. ${ }^{5} \mathrm{~A}$ case might be made for screening for vitamin $\mathrm{D}$ deficiency by measuring plasma $25-\mathrm{OHD}$ concentrations. If this were to be practicable, however, the assay technique would need to be simple and rapid. Previously developed competitive protein-binding assays for 25-OHD are tedious, involving long extraction procedures and chromatographic purifications. ${ }^{6} 7$ This paper describes a simpler technique developed by modifying a method by Belsey et al. ${ }^{8}$

\section{Material and methods}

\section{STEROIDS}

Standard 25-hydroxycholecalciferol $\left(25-\mathrm{OHD}_{3}\right)$ was obtained from the Upjohn Company by courtesy of Dr John Babcock and 25-hydroxy (26(27)-methyl- $\left.{ }^{3} \mathrm{H}\right)$ cholecalciferol $\left({ }^{3} \mathrm{H} 25-\mathrm{OHD}_{3}\right), 12 \cdot 2 \mathrm{Ci} / \mathrm{mmol}$, was purchased from the Radiochemical Centre, Amersham, Bucks, UK.

\section{B U F F E R}

Barbital acetate buffer was prepared by mixing $0.486 \mathrm{~g}$ sodium acetate, $0.787 \mathrm{~g}$ barbitone sodium, and $7.65 \mathrm{~g}$ sodium chloride in 1 litre of water and adjusting the $\mathrm{pH}$ to 8.6 with hydrochloric acid. In order to facilitate solubilisation of steroids, $\beta$ lipoprotein was added to the buffer. A precipitate of this, obtained by the technique of Besley et al., ${ }^{9}$ was washed with ether and then reconstituted to the original volume with barbital acetate buffer. This was added to more buffer at a suitable dilution which maintained non-specific binding at a minimum (1:800).

\section{BINDING PROTEIN}

Serum from weanling rats raised on a vitamin $D$

Received for publication 13 August 1979 deficient diet for at least three weeks was stored at $-20^{\circ} \mathrm{C}$. Before use in the assay this was diluted with buffer to a concentration that gave approximately $50 \%$ binding of ${ }^{3} \mathrm{H} 25-\mathrm{OHD}_{3}$.

DEXTRAN-COATED CHARCOAL

$0.5 \mathrm{~g}$ dextran (molecular weight $60000-90000$ ) and $5.0 \mathrm{~g}$ Norit-GSX charcoal were mixed with $200 \mathrm{ml}$ barbital acetate buffer. This was further diluted with buffer $(1: 10)$ before use.

\section{SCINTILLATION FLUID}

A mixture of toluene and triton X-100 (2:1) was added to 1,4-bis-(5-phenyloxazol-2-yl) benzene and 2,5-diphenyloxazole to give $0.03 \%$ and $0.5 \%$ solutions respectively.

\section{METHOD}

A $200 \mu$ l plasma sample was thoroughly mixed with $0.8 \mathrm{ml}$ ethanol and left at $4^{\circ} \mathrm{C}$ for 30 minutes. On centrifugation $50 \mu \mathrm{l}$ was transferred to a glass assay tube. Another $50 \mu \mathrm{l}$ was added to a control tube to monitor non-specific binding. $50 \mu \mathrm{l}$ aliquots of each of the standards serially diluted in ethanol were transferred to assay tubes. $50 \mu \mathrm{l}^{3} \mathrm{H} 25-\mathrm{OHD}_{3}(0.34$ pmol), also prepared in ethanol, was added to all tubes, followed by $1 \mathrm{ml}$ barbital acetate buffer, containing 25-OHD binding protein, to the assay tubes and $1 \mathrm{ml}$ buffer alone to the control tubes. After mixing, these were left for 2 hours at $4^{\circ} \mathrm{C}$. Unbound steroids were removed using dextrancoated charcoal $(500 \mu \mathrm{l})$ and, after centrifugation, the supernatants were decanted into vials containing $10 \mathrm{ml}$ of scintillation fluid. The radioactivity was counted in a Packard $\beta$-counter. Percentage binding of ${ }^{3} \mathrm{H} 25-\mathrm{OHD}_{3}$ was calculated from-

Counts from assay tube-counts from control tube.

Total counts added

From this a standard curve was obtained by plotting the percentage of bound ${ }^{3} \mathrm{H} 25-\mathrm{OHD}_{3}$ against log mass of 25-OHD 3 (Fig. 1). 25-OHD concentrations $(\mathrm{nmol} / \mathrm{l})$ in individual plasma samples could then be obtained by reference to the standard curve $(2.5$ $\mathrm{nmol} / 1$ is equivalent to $1 \mathrm{ng} / \mathrm{ml}$ ).

\section{Results}

STANDARD CURVE

The standard curve obtained is shown in Fig. 1 and covers the workable range. The sensitivity of the assay system is $5 \mathrm{nmol} / \mathrm{l}$, as defined by Ekins. ${ }^{10}$

\section{PRECISION}

The intra-assay coefficients of variation for 10 samples containing $30 \mathrm{nmol} / \mathrm{l}$ and 10 samples 


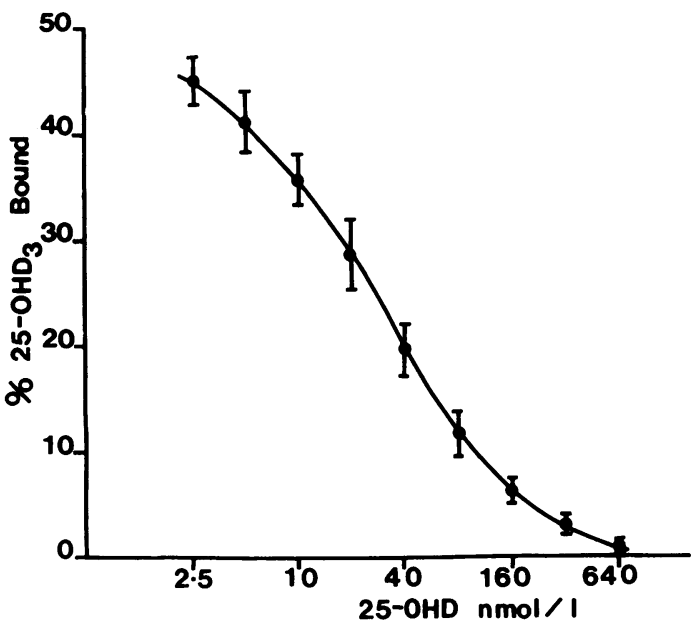

Fig. 1 Standard curve for 25-OHD obtained by plotting $\%$ of bound ${ }^{3} \mathrm{H} 25-\mathrm{OHD}_{3}$ to binding protein against the increasing amounts of $25-\mathrm{OHD}_{3}$ added. Mean values $\pm S D$ of four assays are indicated.

containing $105 \mathrm{nmol} / \mathrm{l} 25-\mathrm{OHD}$ were $2 \%$ and $8 \%$ respectively. The inter-assay coefficient of variation for 24 samples containing $30 \mathrm{nmol} / 1$ was $10 \%$; that for 30 samples containing $105 \mathrm{nmol} / \mathrm{l}$ was $16 \%$.

\section{ACCURACY}

Recovery of ${ }^{3} \mathrm{H} 25-\mathrm{OHD}_{3}$ added to five plasma samples was $97 \pm 3 \%$. A linear regression calculated for estimated 25-OHD against added $25-\mathrm{OHD}_{3}$ gave a correlation coefficient of $\mathbf{0 . 9 8}$.

\section{SPECIFICITY}

Cross-reactivity with different steroids at $50 \%$ displacement from zero binding is shown in the Table. Only 25-hydroxyergocalciferol $\left(25-\mathrm{OHD}_{2}\right)$ and 24,25-dihydroxycholecalciferol $\left(24,25-(\mathrm{OH})_{2} \mathrm{D}_{3}\right)$ caused significant interference.

\section{Cross-reactivity of steroids}

\begin{tabular}{ll}
\hline Steroid & $\begin{array}{c}\% \text { Cross-reaction (at } 50 \% \\
\text { inhibition of binding) }\end{array}$ \\
\hline 25-hydroxycholecalciferol & 100 \\
25-hydroxyergocalciferol & 100 \\
24,25-dihydroxycholecalciferol & 60 \\
1,25-dihydroxycholecalciferol & $0 \cdot 005$ \\
Cholecalciferol & $0 \cdot 6$ \\
Ergocalciferol & $0 \cdot 3$ \\
Cholesterol & None \\
Cholic acid & None \\
Cortisol & None \\
17 $\beta$-oestradiol & None \\
Androsterone & None \\
\hline
\end{tabular}

REFERENCE RANGE

Plasma 25-OHD concentrations in 47 healthy adults aged 19 to 41 years showed a logarithmic distribution giving a geometric mean of $65 \mathrm{nmol} / \mathrm{l}$, with $95 \%$ confidence limits of 20 to $215 \mathrm{nmol} / \mathrm{l}$. A histogram of the distribution of the values is markedly skewed, most values lying below $100 \mathrm{nmol} / \mathrm{l}$ (Fig. 2).

\section{Discussion}

The results confirm a competitive protein-binding assay, without preparative chromatography, that gives valid plasma 25-OHD estimations. The method has limitations of specificity in that, although it measures all $25-\mathrm{OHD}_{3}$ and $25-\mathrm{OHD}_{2}$, it includes variable amounts of $24,25-(\mathrm{OH})_{2} \mathrm{D}_{3}$, thus elevating values slightly. Some subjects, therefore, with actual low concentrations of 25-OHD would present within the reference range while those subjects with real normal levels would continue to exist within this range. In effect, when screening for vitamin D deficiency using this method, some false-negative results may be obtained but no false positives. A more specific test may be indicated in subjects with levels bordering on the lower limit of the reference range.

The assay has the advantage of high precision and speed of performance. The extraction of $200 \mu \mathrm{l}$ of plasma by a small volume of ethanol allows consistent recoveries of over $95 \%$ and removes the need for internal monitoring. Ethanol extracts may, therefore, be used directly in the assay system without reduction under nitrogen.

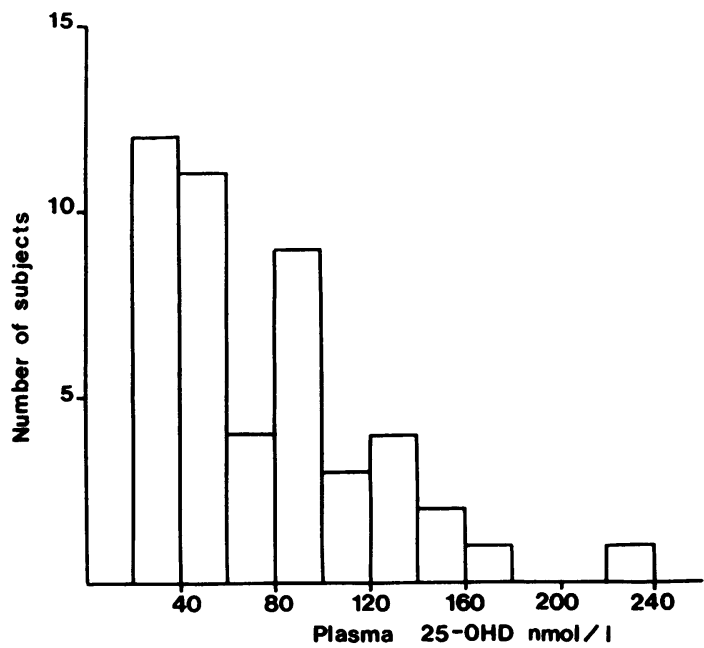

Fig. 2 Distribution of plasma 25-OHD concentrations in healthy young adults. 
The concentrations of 25-OHD in young adults estimated by the technique are comparable with those found by workers using other methods where mean values are $68 \mathrm{nmol} / 1,{ }^{7} 77 \mathrm{nmol} / 1,{ }^{11}$ and 98 nmol/1.12 Studies utilising the technique have included a review of 62 patients admitted to a geriatric unit, assessments of the responses of old people to vitamin supplements and to ultraviolet light, and a large-scale review of 298 old people living at home. ${ }^{13-15}$ The successful completion of such studies gives further support to the view that the technique described in this paper would be of practical value as a method of screening for vitamin D deficiency.

\section{References}

${ }^{1}$ Nayal A S, MacLennan W J, Hamilton J C, Rose P, Kong M. 25-hydroxy-vitamin D, diet and sunlight exposure in patients admitted to a geriatric unit. Gerontology 1978; 24: 117-122.

${ }^{2}$ Fairney A, Naughten E, Oppé T E. Vitamin D and human lactation. Lancet 1977 ; 2 : 739-741.

${ }^{3}$ MacLennan W J, Hamilton J C, Darmady J. The effects of season and stage of pregnancy on plasma 25hydroxyvitamin D concentrations in pregnant women. Postgrad Med J 1980; in press.

${ }^{4}$ Davie M, Lawson D E M, Jung R T. Low plasma 25-hydroxyvitamin D without osteomalacia (Letter). Lancet 1978; 1: 820.

${ }^{5}$ MacLennan W J, Hamilton J C. Low plasma-25hydroxyvitamin $\mathrm{D}$ without osteomalacia (Letter). Lancet 1978; 1 : 1210.
${ }^{6}$ Edelstein S, Charman M, Lawson D E M, Kodicek E. Competitive protein-binding assay for 25-hydroxycholecalciferol. Clin Sci Mol Med 1974; 46: 231-240.

${ }^{7}$ Haddad J G, Chyu K J. Competitive protein-binding radioassay for 25-hydroxycholecalciferol. $J$ Clin Endocrinol Metab 1971; 33: 992-995.

${ }^{8}$ Belsey R E, De Luca H F, Potts J T Jr. A rapid assay for 25-OH-vitamin $\mathrm{D}_{3}$ without preparative chromatography. J Clin Endocrinol Metab 1974; 38: 10461051.

${ }^{9}$ Belsey R E, De Luca H F, Potts J T Jr. Competitive binding assay for vitamın $\mathrm{D}$ and $25-\mathrm{OH}$-vitamin $\mathrm{D}$. $J$ Clin Endocrinol Metab 1971; 33: 554-557.

${ }^{10}$ Ekins R P. Basic principles and theory. Br Med Bull 1974; 30: no 1.3-11.

${ }^{11}$ Corless D, Beer M, Boucher B J, Gupta S P, Cohen R D. Vitamin-D status in long-stay geriatric patients. Lancet 1975 ; 1 : 1404-1406.

${ }^{12}$ Garcia-Pascual B, Peytremann A, Courvoisier B, Lawson D E M. A simplified competitive proteinbinding assay for 25-hydroxycalciferol. Clin Chim Acta 1976; 68: 99-105.

${ }^{13}$ MacLennan W J, Hamilton J C. Vitamin $D$ and 25-hydroxyvitamin $\mathrm{D}$ concentrations in the elderly. Br Med J 1977; 2: 859-861.

${ }^{14}$ Snell A P, MacLennan W J, Hamilton J C. Ultra-violet irradiation and 25-hydroxy-vitamin $D$ levels in sick old people. Age Ageing 1978; 7: 225-228.

${ }^{15}$ MacLennan W J, Hamilton J C, Timothy J T. 25 hydroxyvitamin $\mathrm{D}$ concentrations in old people living. $J$ Clin Exp Gerontol 1980; in press.

Requests for reprints to: Mrs JC Hamilton, Centre Block (Level E), Southampton General Hospital, Tremona Road, Southampton SO9 4XY, UK.

\section{Letters to the Editor}

Failure to demonstrate specificity of the morphological and histochemical changes in mucosa adjacent to colonic carcinoma (transitional mucosa)

We have recently come across a case of primary adenocarcinoma of the caecum invading the appendix, which seems to support the suggestion made by Isaacson and Attwood ${ }^{1}$ that the morphological mucosal hyperplastic changes seen adjacent to large bowel carcinomas are most probably a secondary effect of the tumour presence.
The patient was a 64-year-old woman who presented with a three-year history of abdominal pain and a recent onset of diarrhoea and general weakness. A mass was found in the right iliac fossa and a malignant tumour was diagnosed, for which a right hemicolectomy was performed.

The caecum contained a nodular, ulcerated tumour mass that involved the whole circumference of the caecum and extended vertically for up to $6.0 \mathrm{~cm}$. The tumour was infiltrating the whole thickness of the bowel wall, the ileocaecal region, the base of the appendix, and several mesenteric lymph nodes.

Histologically, the tumour was an adenocarcinoma showing variable degrees of differentiation, some areas being moderately or poorly differentiated and others showing a predominance of 'signet-ring' malignant cells. Stains for argentaffin granules were negative.

Sections of the base of the appendix (Figure) showed tumour tissue, at one side, in lymphatics and invading the wall and adjacent fibrofatty tissue to a variable extent. The appendiceal mucosal epithe- 